\title{
Pendidikan Islam di Mesir
}

Baidarus, Radhiyatul Fithri

Universitas Muhammadiyah Riau, STKIP Aisyiyah Riau

Email: bayu@umri.ac.id, radhiyatulfithri@gmail.com

\begin{abstract}
Abstrak
Penelitian ini bertujuan untuk mengetahui tentang sistem pendidikan Mesir, yang meliputi kebijakan pendidikan seperti lembaga pendidikan, manajemen pendidikan, kurikulum pendidikan, dan pendanaan pendidikan. Metode yang digunakan dalam penelitian ini adalah metode kualitatif dengan pendekatan studi literatur(Library Research). Sumber utama yang dijadikan rujukan adalah buku- buku, artikel ilmiah. Berdasarkan hasil penelitian yang dilakukan bahwa perkembangan kemajuan Mesir dan modernisasi pendidikan dimulai dengan diperkenalkannya kemajuan ilmu pengetahuan dan teknologi oleh Napoleon Bonaparte yang merupakan bangsa Amerika ketika menaklukkan Mesir. Pasca Revolusi Industri, pendidikan di Mesir mengalami hal-hal yang dinamis seperti kurikulum, metodologi dan kebijakan pendidikan yang berbeda pada setiap jenjang pendidikan. Dalam mengelola birokrasi pendidikan, pemerintah Mesir membaginya menjadi dua sistem: sistem pendidikan dasar hingga pendidikan tinggi dan sistem pendidikan tinggi. Sistem sekolah dasar dan menengah disponsori oleh Menteri Pendidikan. Sistem Pendidikan Tinggi disponsori oleh Menteri Pendidikan Tinggi, Riset dan Teknologi lainnya. Pendidikan Al-Azhar saat ini dikelola di semua jenjang oleh Kementerian Urusan Al-Azhar, yang dapat disamakan dengan Kementerian Agama di Indonesia
\end{abstract}

\section{Key Words: Pendidikan Islam di Mesir}

\section{PENDAHULUAN}

Mesir berada di wilayah Afrika Utara. Afrika Utara merupakan wilayah yang sangat penting bagi penyebaran Islam ke daratan Eropa. Kawasan ini menjadi pintu gerbang bagi Islam untuk memasuki wilayah tersebut, yang telah berada dalam kekuasaan Kristen selama berabad-abad, dan juga telah menjadi "benteng" Islam di wilayah ini. Istilah Mesir berasal dari seseorang yang bernama Mishr Ibn Mihsrayim Ibn Ham Ibn Nuh. Mesir memiliki hubungan yang baik dengan Nabi semasa hidupnya. Buktinya adalah istri Rasulullah sendiri, Maria Al-Qibthiyah berasal dari Mesir, dan Rasulullah memiliki anak dari perempuan ini yang bernama Ibrahim. Walaupun hubungan sudah terjalin sejak lama, tetapi Mesir baru menjadi kota
Islam sejak Umar menjabat sebagai khalifah yang menggantikan Abu Bakar yang berkuasa sebelumnya. Mesir ditaklukkan di bawah bimbingan Amru bin Ash ra. Penaklukan Alexandria merupakan tanda bahwa seluruh Mesir berada di tangan kaum Muslimin. Dalam penaklukan, umat Islam tidak punya pilihan lain, kecuali penaklukan Mesir setelah penaklukan Syria dan Palestina. Hal ini dilakukan karena kekhawatiran bahwa Romawi yang memerintah Mesir pada saat itu akan merusak stabilitas wilayah Muslim. Selain itu, umat Islam telah lama mendengar tentang penindasan agama di Mesir oleh penguasa Romawi Heraclius. Alexandria, ibu kota Mesir, jatuh ke tangan tentara Islam pada tahun 641 M. Ketika Mesir jatuh ke tangan Muslim, Amru bin Ash menawarkan 
penduduknya tiga pilihan: menerima Islam, membayar Jizyah, atau berperang. Dengan tiga pilihan ini, namun mereka lebih memilih untuk berperang. Pada akhirnya, mereka kalah dan harus membayar Jizyah. Belakangan, Islam semakin banyak meraih kemenangan di Mesir setelah menaklukkan kota-kota lain di Mesir (Abu Haif, 2015).

Pada masa awal perkembangan Islam, pendidikan Islam belum dilaksanakan secara resmi. Keberlanjutan penyelenggaraan pendidikan Islam dapat dijelaskan secara umum bersifat informal, dalam bentuk upaya penyebaran Dakwah Islam serta penanaman dan penguatan pondasi keimanan dan ibadah Islam. Hal ini mengisyaratkan, bahwa proses pendidikan Islam hanya berlangsung di rumah sahabat yang dikenal dengan Dar al-Arqam. Setelahnya proses pendidikan Islam dilakukan di masjid-masjid. Proses pendidikan di dua lokasi ini berlangsung di halaqah, yang disebut learning circle yang kemudian berkembang menjadi madrasah (Azyumardi Azra, 1999). Timur Tengah merupakan basis lahirnya peradaban Islam, khususnya dalam bidang pendidikan Islam. Sangat menarik untuk ditelaah ketika tren modernisasi sebagai produk peradaban Barat mulai melingkupi hampir seluruh wilayah dunia, termasuk Timur Tengah (Muhammad Ihsan, 2007).

Untuk memahami sistem pendidikan pada suatu negara, latar belakang sistem pendidikan tersebut perlu dipertimbangkan. Latar belakang terselenggaranya sistem pendidikan berupa kerangka sejarah, politik, ekonomi dan sosiologis kondisi negaranegara yang menjalankan sistem pendidikan tersebut sangat mempengaruhi potret implementasi sistem pendidikan di masing-masing negaranya (Dukha Yunitasari, 2017). Misalnya, sistem pendidikan Mesir. Republik Arab Mesir adalah sebuah negara yang sebagian terletak di timur laut Afrika. Dikenal karena peradabannya dan beberapa monumen kuno terbesar di dunia, Mesir secara luas diakui sebagai pusat budaya dan politik utama kawasan Arab dan Timur Tengah. Mesir dikenal sebagai salah satu pusat kebudayaan dunia bahkan pada zaman dahulu. Peninggalan budaya Mesir seperti piramida, sphinx, obelisk dan hieroglif. Ada piramida di Giza dan Sakara (Dukha Yunitasari, 2017). Sphinx ada di Sakara. Julukan untuk tanah Mesir adalah Ardur Anbiyaa' (negeri para Nabi). Ini diberikan karena banyak nabi yang hidup, singgah, atau menetap di negeri itu. Mesir adalah satu-satunya negara yang hidup paling lama di bawah pemerintahan Fatimiyah. Negeri dengan seribu menara ini bukan hanya segudang peradaban, tapi juga harta karun segala ilmu (Dukha Yunitasari, 2017).

\section{METODE}

Metode penulisan artikel ilmiah ini menggunakan metode kualitatif dengan pendekatan studi literatur(Library Research). Sumber utama yang dijadikan rujukan adalah buku- buku, artikel ilmiah.

Pada penelitian kualitatif, kajian pustaka harus digunakan secara konsisten dengan asumsi-asumsi metodologis. Artinya harus digunakan secara induktif sehingga tidak mengarahkan pertanyaanpertanyaan yang diajukan oleh peneliti. Salah satu alasan utama untuk melakukan penelitian kualitatif yaitu bahwa penelitian tersebut bersifat eksploratif. Teknik ini digunakan dengan melakukan 
perbandingan hasil atau temuan-temuan yang terungkap dalam penelitian dengan literatur (Limakrisna, 2016)

\section{HASIL DAN PEMBAHASAN}

Sebelum abad ke-19, sistem pendidikan tradisional diatur oleh pemimpin dan pemuka agama di Mesir. Setelah Revolusi 1919 dan kemerdekaan Mesir pada tahun 1922, babak baru pendidikan Islam Mesir dimulai. Pendidikan dikelola atau dikendalikan oleh Menteri Pendidikan, lebih luas oleh dewan-dewan provinsi (Arief Sukino, 2016). Dengan kata lain, penataan pendidikan dilakukan oleh negara dengan mengutamakan isu-isu teologis di gereja dan masjid dalam bentuk seminar. Sementara itu, di desa-desa diselenggarakan lembaga pendidikan untuk anak-anak yang berfokus pada membaca dan menulis bahasa Arab, belajar matematika, dan belajar ayat-ayat firman Allah dalam al-kitab (Injil) dan firman Allah dalam al-Quran (Suliki, 2021). Lembaga ini dikenal dengan nama Kuttab. Goldziher menerjemahkan kata kuttab dengan maktab dengan elementry school yang bertujuan untuk memberikan pendidikan tingkat pertama kepada anak didik (Said Ismail Ali, 1979). Pada tahun 1937, pemerintah memberikan semua penguasa negara peraturan kuttab kuttab di daerahnya masing-masing. Pada tahun 1938, pemerintah menutup kesenjangan antara kuttab dan sekolah dengan menggeser pendidikan bahasa asing dari tingkat 1 ke tingkat 2. Pada tahun 1944, Departemen Pendidikan memutuskan untuk menghapuskan biaya sekolah dasar. Ini bertujuan untuk mengurangi perbedaan sosial dan mempromosikan pendidikan. Pada tahun 1949, siswa dibebaskan dari pembelian buku (Affan Hassan, et.al., 1983).

Sejak diberlakukannya konsep pendidikan untuk semua (education for all), pemerintahan Mesir mulai terlihat mengalami kemajuan. Sekalipun ketetapan tersebut hanya dikenyam oleh warga Negara yang berstatus sosial elit. Setelah terjadinya revolusi Mesir di tahun 1952 hal ini sangat berpengaruh pada pola fikir warga negaranya khususnya tentang pendidikan. Lebih dari $50 \%$ anak-anak laki-laki telah lulus pendidikan sekolah dasar. Sistem pendidikan Mesir merubah secara dramatik yaitu pendidikan untuk semua warganya (education for all). Pemerintahan Mesir memberikan pendidikan gratis untuk semua warganya. Menteri pendidikan Mesir mengalokasikan anggaranya dari tahun 1952-1953 sebesar 3\%, dan lebih dari $5 \%$ pada tahun 1958. Pengeluaran belanja untuk biaya sekolah meningkat sampai 1000\%, pada tahun 1952- 1976. Di sisi lain warga negaranya meningkat untuk mendaftar sekolah dasar dengan kelipatan 10.000 (Affan Hassan, et.al., 1983).

\section{Regulasi sistem pendidikan di Mesir}

\begin{tabular}{llr}
\multicolumn{1}{c}{ Peraturan } & \multicolumn{1}{c}{ tentang } & sistem \\
pendidikan & pemerintahan & Mesir \\
dimonitoring & dan dievaluasi & oleh \\
kementrian & pendidikan. & Sistem
\end{tabular}
pendidikan yang berlaku di pemerintahan Mesir pada akhirnya beragam. Sistem pendidikan sekuler berbentuk pendidikan untuk publik sementara sistem pendidikan Islam dikelola oleh Universitas al-Azhar yaitu pendidikan privat ditambah dengan keberadaan para pendatang dari negara luar untuk menimba ilmu di Mesir. 
Sistem pendidikan sekuler yang dikelola oleh pemerintahan Mesir berupa pendidikan pra universitas, berupa pendidikan taman kanak-kanak, pendidikan yang berorientasi pada kejuruan dan pendidikan menengah. Sistem pendidikan sekuler pada taman kanak-kanak dimulai pada tahun 1980. Berawal dari tahun 1981 pendidikan taman kanak-kanak di Mesir mulai memperkenalkan program pendidikan dasar. Pada tahun ini juga, pendidikan dasar dan lembaga pendidikan swasta yang berorientasi pada kejuruan diberi mandat sebagai lembaga pendidikan setingkat pendidikan dasar, yang ditempuh selama enam tahun. Namun pada tahun 1988 pendidikan swasta yang berorientasi pada kejuruan di tempuh 9 tahun dan selanjutnya direduksi menjadi delapan tahun (Affan Hassan, et.al., 1983).

Taman Kanak-kanak (TK) di Mesir dikenal dengan istilah Hadonah, yang waktu tempuh pengajarannya lebih kurang sama dengan yang ada di Indonesia yakni selama 2 tahun, berupa tingkat 1 dan tingkat 2. Setelah tamat TK melanjutkan ke jenjang SD (Ibtida'i). Masa belajar di jenjang SD ini hanya selama 5 (lima) tahun yang terbagi menjadi kelas I, kelas II, kelas III, kelas IV dan kelas V/VI. Kelas V/VI ini adalah penggabungan dari kelas $\mathrm{V}$ dan kelas $\mathrm{VI}$ yang dilaksanakan pembelajarannya dalam waktu 1 tahun, dengan sistem pembelajaran pada caturwulan pertama siswa belajar mata pelajaran kelas $\mathrm{V}$ dan pada caturwulan kedua mereka mempelajari mata pelajaran kelas VI.

Evaluasai pembelajaran di Mesir secara umum di setiap tingkat ditentukan oleh Kementerian Pendidikan dan setiap mata pelajaran memiliki tolok ukurnya sendiri. Dalam penilaian kami, jika seorang siswa mendapat 80 dan tolok ukurnya 100, itu berarti 80 dari 100. Hal yang sama berlaku di Mesir, tetapi setiap pelajaran memiliki tolok ukurnya sendiri. Dalam ujian masuk sekolah menengah pertama, skor patokan untuk jumlah mata pelajaran adalah 350 poin. Siswa dengan nilai 185 atau lebih dianggap telah masuk SMP dengan tambahan Bahasa Inggris. Perancis. Pindah ke jenjang SMA selama 3 tahun di kelas yang sama. Nilainya hampir sama, tetapi skor total untuk jumlah total mata pelajaran adalah 250 . Peningkatan siswa dengan skor di atas 185 dapat mendaftar di pendidikan menengah. Jika nilai siswa antara 160 dan 185, dia dapat menghadiri sekolah menengah komersial. Jika Anda tidak mendapatkan nilai yang cukup dan hanya naik, Anda dapat pergi ke sekolah menengah industri. Ada juga sekolah menengah untuk pariwisata dan perhotelan, dan nilai yang diperlukan untuk masuk ke sekolah ditentukan oleh sekolah tempat anda mendaftar dan ratarata adalah nilai industri.

Setiap sekolah memiliki pelajaran tertentu. Untuk lebih jelasnya, pelajaran dan jurusan masing-masing sekolah. Di tingkat SMU, periode kelas adalah 3 tahun. Pada kelas I, caturwulan 3, sekolah meminta siswa untuk memilih mata pelajaran yang akan diambil. Ada beberapa pilihan, seperti sains, matematika, dan sastra. Ketika siswa mengambil sains, mereka menerima kelas wajib: biologi, kimia, dan fisika. Selain itu, siswa harus memilih dua mata pelajaran lain, seperti Ilmu Pengetahuan (nabati, hewani, manusia), geografi, filsafat, dan sejarah. Oleh karena itu, ada lebih banyak mata pelajaran sains daripada mata pelajaran lainnya. 
Mahasiswa yang memilih program studi sains mengikuti akademi (universitas) kedokteran (gigi, mata, dll), apotek, kedokteran hewani, nabati (pertanian), dll. Siswa matematika menerima mata pelajaran wajib dalam kimia, matematika, dan fisika. Selain itu, siswa dapat memilih dari dua mata pelajaran: biologi, geografi, filsafat, dan kemasyarakatan. Siswa yang belajar sastra diberikan mata pelajaran wajib dalam geografi, filsafat, ilmu sosial, sejarah, dan ekonomi. Mata pelajaran pilihan siswa adalah kimia, geografi, matematika, fisika, dan biologi. Setelah itu, dia bisa masuk akademi (perguruan tinggi) seperti penerangan, perdagangan, bisnis dan politik, musik, pendidikan jasmani, pengajaran Arab, kehakiman (pengadilan) dan masih banyak. Di sekolah menengah lain seperti perdagangan, maka pendidikan yang diberi ada pendidikan untuk menjadi "businessman" dengan mata pelajaran seperti komputer, mengetik dan layanan kesekretariatan dan sebagainya, sekolah ini berlangsung selama tiga tahun. Jika hasil SLTP mencapai 200 ke atas maka siswa dapat masuk sekolah menengah perdagangan 5 tahun. dan kemudian akan masuk akademi perdagangan langsung ke tingkat dua. Hal ini juga terjadi di sekolah menengah teknik, sekolah pariwisata dan sekolah perhotelan. Akademi meliputi akademi informasi, barang antik, akademi pariwisata dan perhotelan.

Pendidikan menengah di Mesir sejalan dengan penyelenggaraan pendidikan umum. Pendidikan menengah di Mesir merupakan pilar pendidikan Mesir. Secara objektif cakupan yang diadakan pada level menengah merupakan persiapan untuk menuju jenjang pada universitas dan keterampilan hidup.

Dengan berdirinya sekolah-sekolah dasar dan menengah, kebutuhan akan guru yang berkualitas menjadi keharusan, maka dibuka sebuah pusat pelatihan untuk mendidik guru-guru yang diberi nama Dar-Al-Ulum. Lembaga ini sibuk melatih guru fisika, geometri, ilmu bumi, sejarah, dan khat (tulisan indah). Selain itu, guru perlu dilatih dalam bidang studi yang diajarkan di al-Azhar, seperti alQur'an, juru tafsir, hadits, fiqih, dan bahasa Arab. Dar al-Ulum berusaha menghubungkan bidang studi agama dengan bidang penelitian umum (modern) (Muhammad Ihsan, 2007).

Konsistensi pemerintah Mesir juga terlihat dari keseriusannya dalam menyelenggarakan pendidikan tinggi baik di bidang universitas maupun nonuniversitas. Pendidikan tinggi terdiri dari pendidikan umum dan pendidikan alAzhar. Pendidikan tinggi non-universitas pemerintah Mesir secara konsisten disediakan di fakultas dan institut. Pendidikan dirancang untuk mempersiapkan peserta didik untuk bekerja menjadi inovator di negaranya masing-masing dan meningkatkan kualitas ilmu keislaman (Muhammad Ihsan, 2007).

Pemerintah Mesir melaksanakan sistem pendidikan agama sebagai salah satu misi dan tanggung jawab pemerintah. Menganut pada sistem alAzhar pendidikan agama diadakan pada pra universitas. Ada dua lembaga yang menangani pendidikan: lembaga umum dan lembaga khusus. Sistem al-Azhar berfokus pada pendidikan dasar, pendidikan swasta berbasis kejuruan, dan pendidikan menengah dalam persiapan untuk kuliah. Mahasiswa Universitas al- 
Azhar berhak menjadi universitas negeri hingga pertengahan 1990-an. Namun, sejak tahun itu, Universitas al-Azhar telah memberikan pendidikan agama secara khusus. Setelah itu, Universitas alAzhar menghasilkan generasi ulama. Misi Universitas al-Azhar adalah menghasilkan eksekutif Islam yang berkualitas di bidang ilmu keislaman, seperti bahasa Arab dan ilmu keislaman, bagi orang asing yang belajar di universitas tersebut. Lembaga pendidikan pra-universitas al-Azhar berkembang hampir pada tahun 1960-an, terutama pada tahun 1991/1992 dan 1998/1999. Kurikulum pendidikan al-Azhar mirip dengan kurikulum pendidikan umum. Hanya saja kurikulumnya menitikberatkan pada kajian Islam. Kurikulum pra-universitas lebih menitikberatkan pada nilai-nilai moral dan agama yang terkait dengan rukun Islam. Materi tersebut berkaitan dengan praktik pembelajaran tentang pengembangan iman, kehidupan Nabi, penghafalan al-Qur'an, dan ibadah. Di sekolah dasar, siswa perlu menghafal 20 tahun yang lalu. Menurut United States Agency for International Development (USAID), tidak ada perbedaan yang signifikan antara sekolah umum dan sekolah yang beroperasi di bawah sistem pendidikan al-Azhar (Muhammad Ihsan, 2007).

Hingga saat ini, Mesir memiliki 19 Universitas, dari 19 Universitas 4 di antaranya yang paling banyak di Masuki oleh Mahasiswa Indonesia yaitu AlAzhar, Universitas Kairo, Institut Riset dan Studi Studi Arab, studi-studi Islam Zamalik, institut 3 akademi, 5 institut program pascasarjana, 11 sekolah tinggi negeri, 43 perguruan tinggi swasta dan 4 institut teknik (Hayati, 2013).
Sistem kuliah di Perguruan Tinggi di Mesir

\begin{tabular}{|c|c|c|c|c|}
\hline & $\begin{array}{l}\text { Nama } \\
\text { Perguru } \\
\text { an } \\
\text { Tinggi }\end{array}$ & $\begin{array}{l}\text { Program } \\
\text { p-1 }\end{array}$ & $\begin{array}{l}\text { Progra } \\
\text { m S-2 }\end{array}$ & $\begin{array}{l}\text { Program S- } \\
3\end{array}$ \\
\hline & \begin{tabular}{|l} 
Al- \\
Azhar
\end{tabular} & $\begin{array}{l}\text { Masa } \\
\text { Kuliah } \\
\text { Dibagi } \\
\text { dalam } \\
2 \\
\text { Semeste } \\
\text { r } \\
\text { (paket) }\end{array}$ & $\begin{array}{l}\text { Kuliah } \\
\text { selam } \\
\text { a } 2 \\
\text { tahun }\end{array}$ & $\begin{array}{l}\text { Langsung } \\
\text { mengajuk } \\
\text { an } \\
\text { judul dan } \\
\text { menulis }\end{array}$ \\
\hline 2 & $\begin{array}{l}\text { Univ. } \\
\text { Kairo }\end{array}$ & $\begin{array}{l}\text { Masa } \\
\text { kulih } 8 \\
\text { semeste } \\
\text { r } \\
\text { dengan } \\
\text { sistim } \\
\text { paket }\end{array}$ & $\begin{array}{l}\text { Kuliah } \\
\text { satu } \\
\text { tahun } \\
\text { baru } \\
\text { menul } \\
\text { is }\end{array}$ & $\begin{array}{l}\text { Langsung } \\
\text { mengajuk } \\
\text { an } \\
\text { judul dan } \\
\text { menulis }\end{array}$ \\
\hline 3 & $\begin{array}{l}\text { Institut } \\
\text { Riset } \\
\text { dan } \\
\text { Studi } \\
\text { Arab }\end{array}$ & $\begin{array}{l}\text { Dikelola } \\
\text { oleh } \\
\text { organis } \\
\text { asi } \\
\text { liga } \\
\text { Arab. } \\
\text { Sistem } \\
\text { kuliah } \\
\text { paket } \\
\text { (empat } \\
\text { semeste } \\
\text { r } \\
\text { selma } 2 \\
\text { tahun }\end{array}$ & $\begin{array}{l}\text { Masa } \\
\text { kuliah } \\
2 \\
\text { tahun }\end{array}$ & $\begin{array}{l}\text { Langsung } \\
\text { mengajuk } \\
\text { an } \\
\text { judul dan } \\
\text { menulis }\end{array}$ \\
\hline 4 & $\begin{array}{l}\text { Institut } \\
\text { Studi- } \\
\text { studi } \\
\text { Islam } \\
\text { (Ma'ha } \\
\text { d } \\
\text { dirasaa } \\
\text { t) } \\
\text { Zamali } \\
\text { k }\end{array}$ & $\begin{array}{l}4 \\
\text { semeste } \\
r\end{array}$ & $\begin{array}{l}\text { Masa } \\
\text { studi } \\
2 \\
\text { Tahun }\end{array}$ & $\begin{array}{l}\text { Langsung } \\
\text { mengajuk } \\
\text { an } \\
\text { judul dan } \\
\text { menulis }\end{array}$ \\
\hline
\end{tabular}

Dalam tahun 1962, sebuah akademi wanita juga didirikan dalam kompleks alAzhar, yang kemudian menjadi sebuah universitas (di lingkungan al-Azhar) yang memiliki fakultas kedokteran sendiri. 
Dengan demikian, secara sosiologis, hal ini tentu saja merupakan perubahanperubahan yang mengejutkan. Menurut Harun Nasution, ide memperjuangkan pendidikan bagi kaum wanita pada Islam modern di Mesir ini, pertama kali disampaikan oleh Rifa'ah al-Tahtawi (1801-1873) agar wanita Mesir memperoleh pendidikan yang sama dengan pria. Tujuan pendidikannya agar wanita dapat menjadi isteri yang baik dan dapat menjadi teman suami dalam kehidupan intelek dan sosial, lebih dari itu pendidikan wanita ini juga dalam rangka membentuk kepribadian dan menanamkan rasa patriotisme atau Hubbu al- Watan (Muhammad Ihsan, 2007).

Untuk memajukan pendidikan di Mesir, pemerintah bekerja sama dalam berbagai bentuk dukungan untuk memfasilitasi akses pendidikan bagi rakyat Mesir. Berbagai jenis dukungan yang tersedia termasuk dukungan dari lembaga pendidikan yang berfokus pada mendukung pendidikan dasar, seperti Bank Dunia dan USAID. Bantuan dialokasikan untuk anak-anak, lebih dari 90\% di antaranya tidak ingin bersekolah di sekolah dasar. Bank Dunia juga menawarkan investasi pendidikan dalam teknologi pengembangan pendidikan. Berbeda dengan bantuan yang diberikan oleh UNICEF, bantuan yang diberikan berfokus pada pemberdayaan perempuan. Sementara Pemerintahan Jepang khusus pada keahlian konstruksi.

\section{Kurikulum Pendidikan di Mesir}

Kurikulum yang digunakan di lembaga pendidikan Mesir merupakan hasil kerja tim. Tim kurikulum ini diambil dari para konsultan, supervisor, profesional pendidikan, profesor, dan guru berpengalaman (Abd Rochman
Assegaf, 2003). Kurikulum pendidikan Taman-Kanak-Kanak (TK) di Mesir, membatasi materinya pada menghafal AlQur'an dan tidak mencampurkannya dengan mata pelajaran lain (Ali Jumbulati, 2002). Oleh karena itu, dibandingkan dengan anak-anak di negara-negara Islam lainnya, mereka lebih kuat dan dapat membaca dan menghafal ayat-ayat. Selain itu, kurikulum juga mencakup materi khat alQuran secara rinci.

Isi kurikulum sekolah modern merupakan perpaduan antara ilmu pengetahuan modern dan studi agama. Selain itu, kurikulum di Universitas alAzhar dilengkapi dengan ilmu pengetahuan modern, sehingga memungkinkan para sarjana untuk memahami budaya modern dan menemukan solusi dari masalah yang muncul di zaman modern. Dari segi konten, secara khusus ditujukan untuk pengajaran bahasa asing (Barat) dalam tiga bahasa yang diajarkan di sekolahsekolah Mesir: Inggris, Prancis, dan Italia. Alasannya adalah sebagai berikut: (1) Dalam perkembangan ilmu pengetahuan, seseorang harus dapat mempelajari beberapa bahasa asing yang dapat mendukung perkembangan ilmu pengetahuan, (2) bahwa ilmu pengetahuan serta keunggulan iptek dan seni tidak selayaknya dimiliki oleh satu bangsa saja melainkan harus dimiliki oleh semua bangsa (Muhammad Ihsan, 2007);

Secara rinci gambaran kurikulum pendidikan di Mesir sebagai berikut:

a. Kurikulum tingkat rendah, terdiri dari mata pelajaran pokok yaitu membaca dan menulis, juga diajarkan geografi dan ilmu berhitung. Pelajaran agama juga dijadikan sebagai salah satu mata pelajaran. Selain itu bahasa Arab 
diajarkan juga dan sekaligus berfungsi sebagai bahasa

pengantar.

b. Kurikulum tingkat menengah, mata pelajaran pokok terdiri dari ilmu berhitung, matematika dan bahasa Italia. Bahasa Arab dan bahasa Turki dijadikan mata pelajaran dan sejak tahun 1820 mulai diajarkan bahasa Perancis. Hukum Islam juga diajarkan pada tingkat ini. Ilmu lainnya dijadikan sebagai mata pelajaran pokok pada setiap sekolah menengah sesuai dengan jurusannya masingmasing.

c. Kurikulum tingkat tinggi, kurikulumnya terdiri dari mata pelajaran matematika dan ilmu-ilmu lainnya sesuai dengan jurusannya masing-masing. Bahasa Arab, Turki, Perancis dan Italia juga diajarkan demikian juga pengetahuan agama dijadikan salah satu mata pelajaran (Tiy Kusmarrabbi Karo, 2017).

\section{Manajemen Pendidikan Di Mesir}

Kementerian negara bertanggung jawab atas sistem pendidikan Mesir, seperti; Kementerian Pendidikan bertanggung jawab untuk memulai pendidikan prasekolah melalui pendidikan tinggi dalam perencanaan, kebijakan, kontrol kualitas, koordinasi dan pengembangannya. Pejabat-pejabat pendidikan di tingkat governorat bertanggung jawab bertanggung jawab untuk implementasinya. Menteri bersidang dalam waktu-waktu tertentu dengan dewan-dewan yang berada di bawah kesektariatannya dan sejumlah dewan-dewan lain. Menteri juga memimpin sidang dewan universitas yang bertanggung jawab atas perencanaan dan pembuatan kebijakan. Struktur organisasi gover-norat pada dasarnya mirip dengan struktur organisasi di pusat kementerian tetapi hanya lebih sederhana. Mesir juga dibagi dalam 140 distrik pendidikan dengan jaringan supervisor dan admi-nistrator. Kementerian Urusan Al-Azhar bertanggung jawab mengatasi kebijakan dan perencanaan pendidikan pada Universitas Al-Azhar dan perguruan tinggi serta sekolah-sekolah lainnya dalam lingkungan Al-Azhar (Dukha Yunitasari, 2017).

Mesir adalah salah satu negara yang dijadikan sebagai tempat menimba ilmu. Terutama, menimba ilmu agama di universitas Al-Azhar. Hal yang luar biasa yang ditemukan oleh siapa saja yang menuntut ilmu di universitas Al-Azhar Mesir adalah terdapat beasiswa belajar cukup banyak dan besar. Semuanya tergantung pada hasil belajar masingmasing (Hayati, 2013).

\section{Pendanaan.}

Peningkatan jumlah guru dan sekolah, perbaikan peralatan dan kenaikan harga (termasuk kenaikan gaji) telah menyebabkan kenaikan belanja pendidikan. Dua puluh tiga (23) juta pound Mesir (E) sama dengan UU\$77 juta yang diseleng-garakan pada tahun 1952 naik menjadi E 126 juta pound (UU\$420 juta) tahun 1969. Pada periode yang sama, investasi masyarakat pada pendidikan meningkat dari E2,5 juta pound (UU\$8,4 juta) menjadi E33,3 juta found (UU\$111,2 juta). Sesudah tahun 1970, alokasi dana untuk pendidikan mulai meningkat dengan jumlah yang lebih besar diban-dingkan alokasi sebelumnya. Pada tahun 1984, pengeluaran masyarakat untuk pendidikan mencapai E1,186,5 juta pound (UU\$1,163 juta). Ini berarti 8,9\% dari keseluruhan penge-luaran 
pemerintah atau sama dengan 4,1\% GNP. Pengeluaran pemerintah untuk pendidikan formal pada tahun 1988 adalah $18,55 \%$ dari total pengeluaran untuk masyarakat. Gaji menye-rap $80 \%$ lebih, sementara pengeluaran lain $20 \%$. Investasi untuk gedung me-ningkat pada tahun 1980-an dari 7\% menjadi $13 \%$. Masih saja tidak cukup gedung-gedung sekolah dan apabila seluruh permintaan dipenuhi, pemerintah harus menyediakan biaya lebih dari E3 miliar pound (UU\$2,94 miliar) pada masa 10 tahun yang akan datang. Dari tahun 1964-1978, pengeluaran untuk pendidikan prauniversitas me-ningkat 4 kali lipat, sementara penge-luaran untuk pendidikan tinggi mening-kat lebih dari 5 kali lipat. Pendidikan tinggi dalam tahun 1970 menggunakan 20,4\% dari total pengeluaran pemerintah untuk pendidikan 31,4\% tahun 1978. Dari total anggaran kementerian, pendidikan dasar menerima 44\%. Jumlah ini masih perlu ditingkatkan. Sistem pendidikan saat ini mempertimbangkan sekolah persiapan (sekolah menengah pertama) sebagai jenjang akhir untuk wajib belajar. Ini berarti peningkatan biaya. Gaji guru-guru pada semua level pendidikan telah naik begitu besar antara tahun 1981 dan1988 dibandingkan kenaikan sebelum-nya (Agustiar Syah Nur, 2001)

\section{b. Beasiswa}

Beasiswa Mesir tidak saja didapat Indonesia melalui proses seleksi Departemen agama (DEPAG). Tapi, setelah di Mesir juga bisa. Yaitu, dengan belajar setahun lalu dinyatakan bisa lulus di tingkat pertama, maka mahasiswa bisa mencari lembaga yang siap memberikannya beasiswa. Setelah dinyatakan lulus di tingkat pertama, mahasiswa yang belajar di universitas AlAzhar Mesir dan ingin mengurus beasiswa harus memahami syaratsyaratnya. Pasalnya, tidak semua lembaga beasiswa Mesir sama dalam menentukan syarat. Terutama dalam masalah nilai yang didapat dari hasil ujian di semester satu.

Untuk memudahkan pengurusan beasiswa mesir, seseorang harus memiliki nilai mumtaz, jayyid dan jayyid jiddan. Di mana pun mereka mengajukan lamaran untuk mendapatkan beasiswa akan sangat mudah. Pasalnya, nilai mereka tersebut menunjukkan bahwa mereka adalah orang yang serius dan memiliki semangat tinggi. Meski, sebenarnya nilai dihasilkan belum tentu bisa menjustifikasi asumsi mereka. Sedangkan bagi mereka yang mendapatkan hasil ujian di semester satu dengan nilai maqbul, manqul satu dan manqul dua, kesempatan mereka mendapat beasiswa hanya bisa pada satu lembaga saja. Sehingga, proses mendapatkan beasiswa Mesir bisa dikatakan ada faktor nasib. Selain masalah hasil yang dicapai pada tingkat satu, keberhasilan melewati jenjang tingkat satu juga jadi perhatian lembaga pemberi beasiswa. Jika sudah pernah gagal dalam meluluskan materi di tingkat satu, ia akan sulit mendapatkan beasiswa. Lagi-lagi, mereka melihat tentang keseriusan belajar pemohon beasiswa.

\section{c. Peraturan Setelah Mendapat Beasiswa}

Setelah mendapatkan beasiswa, para penerima harus taat dengan aturan. Seperti bait zakat, ia menetapkan peraturan jika tidak lulus pada tingkat selanjutnya, maka beasiswa diputus. Atau, bila nilai yang dicapai menurun hasilnya dari tingkat sebelumnya, maka 
jumlah uang beasiswa yang didapat juga berkurang (Agustiar Syah Nur, 2001).

Berbeda dengan majelis A'la, ia menetapkan bila dua kali tidak naik, maka beasiswanya diputus. Sedangkan beasiswa dari pihak al-Azhar sendiri, jika sampai dinyatakan tiga kali tidak lulus pada tingkat yang sama maka beasiswa diputus. Inilah sistem beasiswa Mesir. Seseorang dengan mudah mendapatnya dan juga dengan mudah kehilangannya. Semuanya tergantung bagaimana mahasiswa belajar lebih serius setelah mendapatkan beasiswa. Pasalnya, seseorang akan memiliki peluang untuk mendapatkan peningkatan beasiswa, khususnya yang mendapat beasiswa di bait zakat. Mesir menerima bantuan dari Bank Dunia, UNISEF, UNESCO dan Negara-Negara Sahabat Amerika Serikat (Ali Jumbulati, 2002).

Berdasarkan uraian di atas dapat dipahami bahwa Mesir adalah negara yang sangat memperhatikan pendidikan bagi warga negaranya termasuk warga negara asing. Dengan mencanangkan pendidikan untuk semua (education for all). Kesuksesan Mesir dalam melaksanakan program pendidikan juga tidak lepas dari bantuan lembaga dunia yang ada.

\begin{tabular}{llr}
\multicolumn{1}{c}{ Dalam upaya } & \multicolumn{2}{c}{ memajukan } \\
pendidikan di mesir, & \multicolumn{2}{c}{ pemerintah } \\
melakukan berbagai kerjasama & dalam \\
berbagai bentuk bantuan & untuk \\
kemudahan-kemudahan bagi & warga
\end{tabular} negara mesir dalam mengikuti pendidikan. Dari berbagai bantuan yang ada dianataranya adalah bantuan dari lembaga bantuan pendidikan seperti World Bank dan USAID yang fokus pada bantuan pendidikan dasar. Alokasi bantuan tersebut diberikan pada anak yang lebih dari $90 \%$ tidak berkenan untuk bersekolah di sekolar dasar. Di samping itu World Bank juga memberikan investasi pendidikan pada teknik pengembangan pendidikan. Lain halnya bantuan dari UNICEF, bantuan yang diberikan fokus untuk pemberdayan perempuan. Sementara Pemerintahan Jepang khusus pada keahlian konstruksi.

\section{KESIMPULAN}

Berdasarkan uraian sebelumnya, ada beberapa poin penting yang perlu menjadi perhatian kita terkait dengan sistem pendidikan Mesir, yaitu: Pertama, dasar filosofis pendidi-kan Mesir bertujuan mendidik akal dan jiwa serta mengembangkannya hingga batas-batas yang memungkinkan peserta didik mencapai kebahagiaan hidup di dunia dan di akhirat sehingga terwujud pribadi Muslim. Kedua, sebagai negara yang berpenduduk mayoritas Muslim (94\%) dan menganut agama Islam yang kuat, Me-sir memiliki standar untuk pendidikan Islam dan menjamin kelulusan pendidi-kan keagamaan memiliki pengetahuan dan pemahaman agama yang kuat. Ketiga, perhatian pemerintah Mesir terhadap dunia pendidikan cukup tinggi. Ada satu slogan yang pernah populer di Mesir, yaitu "Pendidikan adalah hak setiap penduduk, seperti air dan udara". 


\section{DAFTAR PUSTAKA}

AbdRochman Assegaf, Internasionalisasi Pendidikan, Sketsa Perbandingan Pendidikan di Negara-Negara Islam dan Barat. Yogyakarta: Gama Media, 2003.

Abu Haif, Sejarah Perkembangan Peradaban Islam di Mesir. Jurnal Rihlah. Vol. II No. 1, 2015.

Ali Jumbulati, Abduh Futuh AtTuwaanisi. Jakarta: Rineka Cipta, 2002

Ali, Said Ismail, Ma'ahid al-Ta'lim alIslam. Cairo: Dar al- Tsaqofah, 1979.

Arief Sukino, Dinamika Pendidikan Islam Di Mesir Dan Implikasinya Terhadap Transformasi Keilmuan Ulama Nusantara. Studia Didaktika: Jurnal Ilmiah Pendidikan. Vol.10 No.1 Issn 1978-8169, 2016

Azra, Azyumardi, Pendidikan Islam: Tradisi dan Modernisasi Menuju Millenium Baru. Jakarta: Logos Wacana Ilmu, 1999

Dukha Yunitasari, Memetik Pelajaran Dari Sistem Pendidikan Mesir Untuk Peningkatan Pendidikan Indonesia. Jurnal Ppkn \& Hukum. Vol. 12, 2007

Hassan, Affan, et.al., 1983. Pendidikan Islam di Indonesia dan Mesir: Titik Berat pada SMP-SMA. Cairo: KBRI Bidang Pendidikan dan Kebudayaan

Hayati, Perbandingan Pendidikan Antara Negara Mesir dan Sudan. Serambi Tarbawi: Jurnal Studi Pemikiran Riset dan Pengembangan Pendidikn Islam. Vol. 01, No. 02, 2013
Muhammad Ihsan, Pendidikan Islam Dan Modernitas Di Timur Tengah: Studi Kasus Mesir. Jurnal Hunafa. Vol. 4, No. 2, 2007

Philip K. Hitti, History of The Arab. Jakarta: Serambi Ilmu Semesta, 2008

Saliyo, Pendidikan Islam Di Mesir Dan Malaysia Di Era Globalisasi Kajian Psikologi Positif. Edukasia: Jurnal Penelitian Pendidikan islam. vol. 13, no. 1, 2018.

Suliki, Dinamika Pendidikan dan Dakwah pada Masa Mesir Modern. Jurnal Studi Islam dan Kemuhammadiyahan (JASIKA). Volume 1, Nomor 1, 2021.

Tiy Kusmarrabbi Karo, Modernisasi Pendidikan Islam Di Mesir. Jurnal WARAQAT. Volume II, No. 2, 2017. 